\title{
Employment-Growth Nexus within the East African States
}

\section{Peter Ainomugisha1, Dickson Turyareeba ${ }^{2,3}$, Robert Ndyanabo Mbabazize ${ }^{4}$, Vincent Katutsi², Alex Atwine ${ }^{5}$}

${ }^{1}$ Ministry of Finance, Planning and Economic Development, Kampala, Uganda

${ }^{2}$ Makerere University Business School, Kampala, Uganda

${ }^{3}$ King Ceasor University, Kampala, Uganda

${ }^{4}$ Bank of Uganda, Kampala, Uganda

${ }^{5}$ MasterLinks Uganda Ltd. and Lecturer, King Ceasor University, Kampala, Uganda

Email: ainopeter@yahoo.com,dturyareba@mubs.ac.ug,mbabazize@gmail.com,vkatutsi@mubs.ac.ug, atwinealex@gmail.com

How to cite this paper: Ainomugisha, P., Turyareeba, D., Mbabazize, R. N., Katutsi, V., \& Atwine, A. (2020). Employment-Growth Nexus within the East African States. Modern Economy, 11, 1836-1857. https://doi.org/10.4236/me.2020.1111124

Received: September 18, 2020

Accepted: November 21, 2020

Published: November 24, 2020

Copyright (C) 2020 by author(s) and Scientific Research Publishing Inc. This work is licensed under the Creative Commons Attribution International License (CC BY 4.0).

http://creativecommons.org/licenses/by/4.0/

(c) (i) Open Access

\begin{abstract}
This paper examines the causal link between economic growth and employment growth in the three traditional East African countries. Time series quarterly data for the period 2001-2018 are used to study the underlying linkage. The study employs the ARDL bounds testing approach to cointegration to estimate the short run and the long run national employment elasticities of economic growth. Estimates show that there is no long run causal link between economic growth and employment growth for Uganda and Tanzania, but there is a long run causal link between the two variables for Kenya. Estimates further show that there is no short run causal link between economic growth and employment growth for Uganda and Kenya but there is a short run causal link between the two variables for Tanzania. In all countries, estimates indicate that the employment intensity of economic growth is less than unity suggesting that the economic growth in the three traditional East African countries has not been employment intensive. The study results provide empirical evidence of the inability of economy expansion of the East African economies to create substantial opportunities for employment for the East African labour force. Results suggest that East African governments need to design policies and implement projects and programs that are pro-poor and are growth inclusive in order for the economy expansion to create more opportunities for job creation.
\end{abstract}

\section{Keywords}

Employment Intensity of Economic Growth, ARDL Bounds Testing, East Africa 


\section{Introduction}

Job creation and economic growth are considered as main issues in economic policies around the world (Choi \& Kim, 2018). Policy makers especially in the labour markets need to understand the link between employment and economic growth of a nation. This linkage is commonly measured by the employment intensity of economic growth. Employment elasticities provide a numerical measure of how employment growth varies with growth in economic output (Thuku et al., 2019). The type of economic growth (extensive or intensive), is an important factor that determines the rhythm of job creation in relation to economic growth. Islam (2004) suggests that the overall employment intensity of growth should be measured by the GDP elasticity of employment: the proportionate change in employment divided by the proportionate change in GDP. The high employment intensity indicates that growth in output leads to considerable job creation while low estimates of employment intensity suggest little correlation between economic growth and employment. Some scholars however posit that higher productivity growth may limit the relationship between economic growth and employment. Economists however generally agree that high and sustainable levels of growth in income would culminate in more employment, eliminate distributional imbalances and reduce poverty. Particularly when GDP grows quicker than its potential, economic growth is high enough to generate jobs. In principle, employment-intensive growth ${ }^{1}$ would be the desirable outcome of economic growth in a sense that growth is expected to be the means for achieving the goals of full employment and rapid rate of poverty reduction (Islam, 2010). A much bigger perspective of this claim was advanced by Malmaeus (2010) who noted that most other goals in society will be more effectively achieved if the economy gets bigger. Kapsos (2005) and Dopke (2001) emphasize that there is a positive relationship between growth in output and growth in employment in that economic growth can create new jobs at levels varying over periods and countries, and that this reflects different reactions by labor markets to the economic growth. Schmid (2008) suggests that both extensive and intensive growth models are important to the possibility of job creation.

From the year 2001 to the year 2018, even amidst the global economic recession of 2008, virtually all the East African countries on aggregate registered healthy rates of economic growth. For instance, according to the 2019 WDI statistics, the three traditional East African countries of Uganda, Kenya and Tanzania collectively registered an impressive average annual growth rate in GDP of 5.9 percent over the period 2001-2018 (Uganda 6.4 percent, Kenya 4.9 percent, and Tanzania 6.5 percent). The state of East Africa press release report 2016 published by the Society for International Development (SID) reported that East African states recorded an average increase in growth rate in aggregate GDP of 6 percent between 2011 and 2016. Surprisingly however, over the same period, the ${ }^{1}$ This represents situations where high growth of employment goes together with high growth in output. More specifically, employment-intensive growth is attained when a 1 percent growth generates a 1 or more percent growth in employment. 
overall growth in employment for the three East African countries has lagged behind the aggregate growth in output. For instance, over the period 2001-2018, according to the 2019 WDI, total employment in all the East African countries grew at an aggregate rate of 3.3 percent (Uganda 3.7 percent, Kenya 3.5 percent and Tanzania 2.8 percent). As a general finding, recent research shows that both poverty and employment intensity of economic growth in many developing countries has been rather low and declining despite the fact that many of these countries have continued to record impressive national economic growth. What is surprising is that this trend has been experienced in the surplus-labour countries where high rates of growth in population and labor force are registered. Thus despite the intuitive notion that growth matters for employment creation, there is empirical evidence contrasting this relationship. Against this backdrop, this study aims to examine the link between employment and economic growth within the three traditional East African countries.

\subsection{The Research Problem}

Empirical literature suggests that the advance in economic growth in Africa is failing to translate into job creation (see for example UN, 2014). This claim does not isolate countries in the East African region. Many empirical studies on the link between employment and growth in output have found significant differences in employment elasticities across different countries with limited attention to the East African Economies. There is nevertheless some ample literature on growth performance in these countries, having recorded impressive economic growth particularly in the last two decades to 2018. On the other hand, these countries continue to experience disappointing growth in total employment, despite the intuitive notion that growth is expected to be the means for more employment. This situation has given rise to a concern that these countries may be experiencing jobless growth. This study is prompted to provide an empirical standpoint as to the link between economic growth and employment within the traditional East African countries.

\subsection{Research Question}

This study addresses one key research question: Is there a causal link between economic growth and employment growth in the traditional East African countries?

\subsection{Study Hypothesis}

This study tested one key research hypothesis, namely, Ho: There is no causal link between employment growth and economic growth in the traditional East African countries.

\subsection{Purpose of the Study}

The main purpose of the study is to examine the link between employment and economic growth in the traditional East African countries for the period of 
analysis 2001-2018.

\subsection{Conceptual Framework}

Unlike many empirical studies which have estimated employment elasticity coefficient by solely linking employment to output growth, this study takes on the idea originally introduced by Revenga \& Bentolila (1994) where the authors implicitly included control variables in the employment-growth functional relationship. In the current study, the control variables capture both the supply-side factors and the demand-side factors that idiosyncratically affect variations in the growth rate of employment of a given country.

The conceptual framework depicted in Figure 1 shows a conceptual link between employment growth and its determinants. The critical determinant of employment growth the study focus on is growth in output, controlling for demand-side and supply-side factors of employment as well as macroeconomic factors which may as well influence variations in country's employment growth.

\section{Literature Review}

\subsection{The Concept of Employment-Growth Elasticity}

Accelerating growth and expanding employment opportunities are the goals of economic policy (Rangarajan, 2006). Employment-growth elasticity or the elasticity of employment growth with respect to output growth is one indicator widely used for analysing the operation of the labour market, hence a basis for inclusive growth. It measures the percentage changes in employment induced by changes in GDP. More specifically, the words employment-growth elasticity shows how much change in employment that is associated with a one percent change in output. The employment-growth elasticity is a quantitative measure of the "employment intensity" of growth. This measure is handy to policy makers

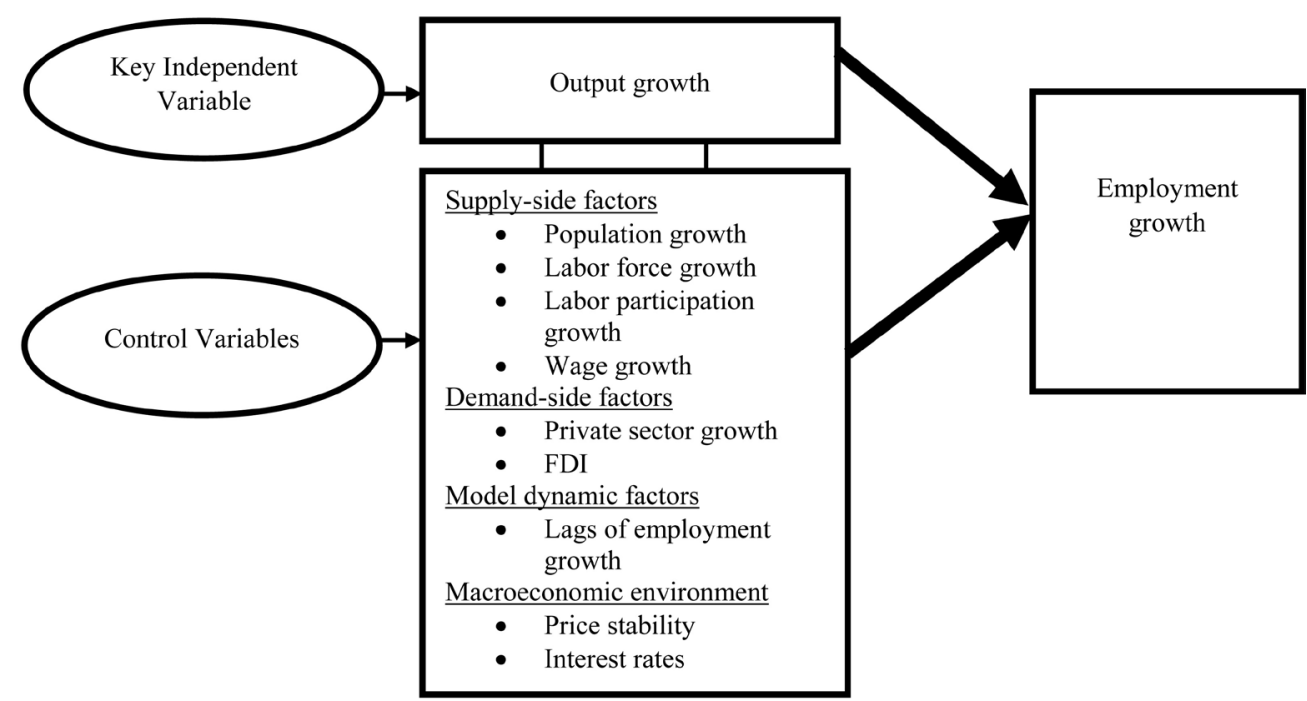

Figure 1. Conceptual framework for the determinants of employment growth. Source: Adopted from Revenga \& Bentolila (1994) and modified by the authors. 
in various ways: 1) The coefficient provides a useful way to examine how economic output, employment and productivity evolve together over time; 2) It provides insights on the economies' capacity to create employment and employment/productivity trade-offs; 3) The sectoral employment-growth elasticities are useful for analyzing structural changes in employment for example movement from agriculture to higher value added sectors such as industry.

\subsection{Link between Economic Growth and Employment: The Okun's Law}

Economists track the relationship between jobs and growth using Okun's Law. The Economist Arthur Okun first started tackling the discussion of the relationship between growth and employment in the 1960s. In its most basic form, Okun's law says that higher growth rate in GDP leads to lower unemployment rate. Okun's law is intended to tell us how much of a country's gross domestic product (GDP) may be lost when the unemployment rate is above its natural rate. According to Okun's law, output depends on the amount of labor used in the production process. Therefore, there is a positive relationship between output and employment. In many empirical studies, the findings show a striking variation across countries in how employment responds to GDP growth over the course of a year.

\subsection{The Aggregate Production Function}

The starting point of relationship between economic growth and employment is the aggregate production function introduced by Solow (1956). The aggregate production function links the amount of output produced in an economy to the inputs of labour (or employment), capital stock as wells as to the state of technical knowledge. Accordingly, output grows through increases in the inputs of factors of production namely Labour $(N)$ and physical Capital $(K)$. Even if $K$ and $N$ were fixed in quantity, still output would grow through improvements in technology $(A)$. Thus an aggregate can be written as:

$$
Y=A F(K, N) \text {; }
$$

where $K$ denotes physical capital, $N$ denotes Labour and $A$ denotes the state of technology or knowledge. The production function in (1) states that output depends on the factor inputs, $K$ and $N$ and on the state of technology. Solow (1956) noted that any increase in output could come from one of three sources: An increase in employment $(L)$, an increase in the stock of capital $(K)$ and increase in multifactor productivity or knowledge $(A)$. Solow (1956) notes if the government can increase the number of people willing and able to seek paid work, then the employment rate increase leads to a higher output of goods and services.

\subsection{A Review of Empirical Literature on Employment Intensity of Economic Growth}

Many empirical studies have found significant differences in employment elas- 
ticities between different countries. For instance, Turyareeba et al. (2020) did study is to examine the link between economic growth and employment growth in Uganda. The authors used quarterly time series for the period 2001-2018. Their study employed a single-equation based Engel-Granger Two-step Error Correction Mechanism is used to estimate the coefficients of the empirical model. The study found that whereas employment growth and economic growth showed no causal link in the short run, the two variables showed a positive and statistically significant causal link in the long run. Manh et al. (2014) examined the relationship between employment and economic growth during the period 1991-2012 in Vietnam and obtained forecasts for employment from 2013 to 2020 , using theories of production function for establishment of econometric models. The results showed that the employment elasticities of economic growth were $-0.49 ; 0.55$ and 0.66 for agriculture, manufacturing and service sectors respectively and 1.71 for Vietnamese economy as a whole in the period. In a study to examine the relationship between economic growth and employment, Seyfried (2011) employed the fixed-effects estimation technique for the pooled regression and the SUR technique for state-specific models to estimate the employment intensity of economic growth for ten largest states in the Unites States of America for the period 1990-2003. The employment intensity was estimated to range from 0.31 to 0.61 in specific states with an estimate of 0.47 for the US as a whole. Results from the study indicated that though economic growth had some immediate impact on employment, there was a lag with the effects taking several quarters to be fully felt in most of the states considered. By employing the Shapley decomposition method to untangle the roles of output per worker, employment, and population structure in growth changes at the aggregate and sectoral levels, complemented with econometric estimation of employment intensity of growth, Ajakaiye et al. (2016) launched a study to examine the relationship between growth and employment in Nigeria in order to gain insights into the country's paradox of high economic growth alongside rising poverty and inequality. The study used annual data for the period 2005-2014. The findings indicated that Nigeria's growth was "jobless" and sustained largely by factor reallocations rather than productivity enhancement. Thuku et al. (2019) conducted a study to determine employment elasticities in priority sectors in Kenya. The authors estimated a double-log linear model that relates total employments units and GDP using the OLS approach. The study found that employment elasticities within priority sectors ranged from 0.115 to 0.412 . The authors concluded that that all the priority sectors were employment inelastic suggesting that although output within the priority sectors continued to grow, the gain in output growth was based on productivity growth rather than employment growth. Choi (2007) used time series data on GDP, employment and wages for the period 1971-2005 to examine the employment effects of economic growth for the Korean economy. The study found that the employment elasticity for Korean economy ranged between 0.49 and 0.38 . The study further revealed that employment elasticity was determined by preference and technology parameters. Using annual data for 
the period 1980-2011, Leshoro (2014) conducted a study to estimate the national employment elasticity of economic growth and to examine the employment elasticities for various sectors in Botswana. The author employed the Error Correction Mechanism to estimate the employment elasticities of economic growth. The study found that employment elasticity of growth of total GDP for Botswana was negatively related to employment growth, but the coefficients of the sectoral GDP contribution had positive effects on employment. In a study by Mouelhi \& Ghazali (2014) to estimate the national employment elasticity of economic growth for Tunisia as well as estimating sectoral employment elasticities, the authors estimated the empirical models using OLS approach by utilizing time series data for the period 1980-2012. The study found that there was a significant decrease in total employment elasticity from 0.61 in 1980-1989 to 0.57 in 1991-1999 and 0.48 in 2000-2012. The study further revealed that agriculture and fishing, trade and tourism were the most labor-intensive sectors. In other related studies, significant differences in employment elasticities were detected by Padalino \& Vivarelli (1997) who reported an elasticity of approximately 0.5 for the United States and Canada while elasticities for Japan, France, Germany, Italy and the UK were close to zero. Pini (1997) detected negative employment elasticities in Italy and Sweden for the period 1990-95. Boltho \& Glyn (1995) detected Elasticity coefficients ranging from 0.5 to 0.6 for a set of OECD countries. Walterskirchen (1999) found employment elasticities for the EU of 0.65 when employing a cross-country analysis of EU countries from 1988-98.

From the literature reviewed, the studies done on the link between economic growth and employment have reported mixed results, and some authors report a negative causal connection between the two variables while others report a positive causal link. What is quite clear and frequently common however is that most countries have recorded economic growth that is not employment intensive. There is also limited empirical evidence on growth-employment linkage within the East African region. Only a few studies have studied Kenya and Uganda. This study adds to the existing literature on the subject by examining the link between growth in employment and growth in GDP within the traditional East African countries.

\section{Methodology}

This study adopts a causal relationship research design. The study utilizes secondary data which has been obtained from World Bank Development Indicators (WBI) and UNCTAD data files. Additional data has been obtained from Kenya National Bureau of Statistics, Tanzanian National Bureau of Statistics and the Uganda Bureau of Statistics. Quarterly data for the period 2001-2018 is used for empirical analysis. This span of data analysis has been particularly chosen because of the two major reasons: 1) Global attention to African growth began in the year 2001 when some of the fastest growing countries in the world were cited on the African continent, some of which are in the East African Region, and 2) The time span enables availability of most the observations on key variables to be considered for empirical analysis. 
The study conducts various diagnostic tests to assess data behavior prior to model estimation. The tests conducted in this study include: 1) Unit root tests, which has been done by the Augmented Dicker-Fuller (ADF) test procedure, initially demonstrated by MacKinnon (1996) to test for stationarity of the variables in the empirical model. This unit root test controls for first order serial correlation which suits time series data sets that are relatively small. Indeed, the test is suitable for the current data set which span 2001-2018; 2) the Cointegration test, which has been conducted to empirically analyze the long-run relationships and short run dynamic interactions among the variables in the model being estimated. The cointegration test has been implemented by the Pesaran et al. (2001) ARDL bounds testing approach. This approach is based on the assumption the model variables have mixed orders of integration, some may be I (0) and others may be I ( 1$)$. The orders of the ARDL $\left(p, q_{1}, q_{2}, q_{3}, q_{4}, q_{5}, q_{6}\right)$ model in the six variables are selected using AIC.

On model specification, we apply a general VAR model of order $P$, in $Z$, where $Z$ is a column vector composed of first differenced regressor variables: $Z$ = (logarithm of GDP, logarithm of domestic credit, logarithm of FDI, population growth, inflation, lending interest rates). The regressor variables in the $Z$-column vector that are continuous and are not measured in percentages are log-transformed while the continuous variables that are measured as percentages are left in original units. This variable treatment guarantees variable normalization and enables estimation of economically meaningful coefficients of the regression model. The study adopts a linear econometric specification between employment and its determinants in the framework adopted by Belloumi (2014). For each country, the study specifies a general multivariate dynamic Employment-Growth econometric relationship as follows:

Uganda:

$$
\begin{aligned}
\Delta \log (\text { empl })_{t}= & \alpha_{01}+\alpha_{11} \log (\text { gdp })_{t}+\alpha_{21} \log (\text { domcred })_{t}+\alpha_{31} \log (\text { fdi })_{t} \\
& +\alpha_{41} \operatorname{popg}_{t}+\alpha_{51} \inf _{t}+\alpha_{61} \operatorname{lr}_{t}+\sum_{m=1}^{p} \beta_{1 j} \Delta Z_{m t-i}+\varepsilon_{1 t}
\end{aligned}
$$

Kenya:

$$
\begin{aligned}
\Delta \log (\text { empl })_{t}= & \alpha_{02}+\alpha_{12} \log (\text { gdp })_{t}+\alpha_{22} \log (\text { domcred })_{t}+\alpha_{32} \log (\text { fdi })_{t} \\
& +\alpha_{42} \text { popg }_{t}+\alpha_{52} \inf _{t}+\alpha_{62} \operatorname{lr}_{t}+\sum_{m=1}^{p} \beta_{1 j} \Delta Z_{m t-i}+\varepsilon_{2 t-i}
\end{aligned}
$$

Tanzania:

$$
\begin{aligned}
\Delta \log (\text { empl })_{t}= & \alpha_{03}+\alpha_{13} \log (\text { gdp })_{t}+\alpha_{23} \log (\text { domcred })_{t}+\alpha_{33} \log (\text { fdi })_{t} \\
& +\alpha_{43} \operatorname{popg}_{t}+\alpha_{53} \inf _{t}+\alpha_{63} \operatorname{lr}_{t}+\sum_{m=1}^{p} \beta_{1 j} \Delta Z_{m t-i}+\varepsilon_{3 t-i}
\end{aligned}
$$

where: empl is total employment in country $j$ at time, $t$, gdp is total GDP of country $j$ at time $t$, domcred is domestic credit to the private sector of country $j$ at time, fdi is foreign direct investment of country $j$ at time, popg is population 
growth of country $j$ at time, inf is of country $j$ at time, $1 \mathrm{r}$ is inflation rate of country $j$ at time, log stands for logarithm, $\Delta$ is a first difference operator; $p$ is the maximum lag length in the dynamic model, $Z$ is a vector of the first differenced regressor variables and $\varepsilon$ is a disturbance term.

The regression coefficient $\alpha_{1 j}$ and the regression coefficient $\beta_{1 j}$ which multiplies $\Delta \log (\mathrm{gdp})_{t-1}$ are the focus coefficients of the estimated model, and define. Particularly,

The LR national employment elasticity of economic growth =

$$
\alpha_{1 j}=\frac{\partial \Delta \log (\text { empl })_{t}}{\partial \log (\mathrm{gdp})_{t}}=\frac{\partial \mathrm{empl} / \mathrm{empl}}{\partial \mathrm{gdp} / \mathrm{gdp}} ;
$$

The SR national employment elasticity of economic growth =

$$
\beta_{1 j}=\frac{\partial \Delta \log (\mathrm{empl})_{t}}{\partial \Delta \log (\mathrm{gdp})_{t-1}}=\frac{\partial \Delta \mathrm{empl} / \Delta \mathrm{empl}}{\Delta \partial \mathrm{gdp} / \Delta \mathrm{gdp}} ;
$$

\section{Results}

\subsection{Descriptive Statistics on Key Variables}

The descriptive statistics in Table 1 indicate that over the study period, Uganda recorded quarterly mean growth rate of approximately 6.4 percent, Kenya recorded approximately 4.9 percent and Tanzania recorded approximately 6.5 percent. All the traditional East African countries taken together recorded a quarterly mean growth rate in GDP of approximately 5.9 percent. Considering all the east African countries, the descriptive statistics in Table 1 show that the maximum quarterly rate of growth in GDP was recorded in Uganda at about 11 percent, and this impressive growth rate in GDP in Uganda was recorded in quarter 3 of 2006. This remarkable quarterly growth rate in GDP may have followed the Uganda government initiatives of implementing pragmatic programs to fight poverty, for instance, the introduction of the "Prosperity For All" initiative in 2006 as a way of refocusing the fight against poverty at a household level. This initiative aimed at giving micro-credit to the "economically active poor" throughout the country, and this may have sparked improved production at the grassroots levels that finally resulted in high growth at a national level, especially in quarter 3 of 2006.

On the other hand, the descriptive statistics in Table 1 show that the minimum quarterly rate of growth in GDP was recorded in Kenya at about -0.3 percent, and this minimum growth rate in GDP in Kenya was recorded in quarter 3 of 2008. This miserable growth rate could have culminated from the political crisis that rocked Kenya flowing Kenya's Presidential Elections of 2007. The descriptive statistics in Table 1 further indicate that the standard deviation in quarterly rate of growth in GDP is more less the same for Uganda and Kenya at about 2.1 percent, higher than that for Tanzania estimated at approximately 1.8 percent indicating that Uganda and Kenya showed closely the same variability in quarterly growth rates in GDP over the study period, but this variability was 
Table 1. Descriptive statistics on quarterly "growth in GDP" and "growth in total employment" for the period $2001 q_{1}-2018 q_{4}$.

\begin{tabular}{ccccccccc}
\hline $\begin{array}{c}\text { Descriptive } \\
\text { statistics }\end{array}$ & \multicolumn{2}{c}{ Mean } & \multicolumn{2}{c}{ Maximum } & \multicolumn{2}{c}{ Minimum } & Std. Dev \\
\hline Variable & $\begin{array}{c}\text { Quarterly } \\
\text { growth rate } \\
\text { in GDP (\%) }\end{array}$ & $\begin{array}{c}\text { Quarterly growth } \\
\text { rate in Total } \\
\text { Employment (\%) }\end{array}$ & $\begin{array}{c}\text { Quarterly } \\
\text { growth rate } \\
\text { in GDP (\%) }\end{array}$ & $\begin{array}{c}\text { Quarterly growth } \\
\text { rate in Total } \\
\text { Employment (\%) }\end{array}$ & $\begin{array}{c}\text { Quarterly } \\
\text { growth rate } \\
\text { in GDP (\%) }\end{array}$ & $\begin{array}{c}\text { Quarterly growth } \\
\text { rate in Total } \\
\text { Employment (\%) }\end{array}$ & $\begin{array}{c}\text { Quarterly } \\
\text { growth rate } \\
\text { in GDP (\%) }\end{array}$ & $\begin{array}{c}\text { Quarterly growth } \\
\text { rate in Total } \\
\text { Employment (\%) }\end{array}$ \\
\hline Uganda & 6.434359 & 3.710887 & 11.12800 & 5.475234 & 2.582178 & 2.718890 & 2.102658 & 0.689964 \\
Kenya & 4.898180 & 3.513342 & 8.811913 & 5.619670 & -0.29211 & 0.667009 & 2.144189 & 1.401918 \\
Tanzania & 6.464138 & 2.818757 & 7.927792 & 3.330755 & 4.274073 & 1.624450 & 0.849495 & 0.475702 \\
\hline
\end{tabular}

Source: Authors' computations based on raw data.

higher than that of Tanzania. This suggests that Tanzania recorded relatively more stable rates in quarterly growths in GDP than Kenya and Uganda over the study period.

On total employment, the descriptive statistics in Table 1 indicate that over the study period, Uganda recorded a mean quarterly growth rate in total employment of approximately 3.7 percent, Kenya recorded a mean quarterly growth rate in total employment of approximately 3.5 percent while Tanzania registered a mean quarterly growth rate in total employment of approximately 2.8 percent. The descriptive statistics in Table 1 indicate that the highest rate of growth in total employment was recorded in Uganda at about 5.7 percent per quarter, and this highest quarterly growth rate in total employment in Uganda was recorded in quarter 2 of 2012. On the other hand, the descriptive statistics in Table 1 indicate that the lowest quarterly rate of growth in total employment was recorded in Kenya at about 0.66 percent, and this lowest quarterly growth rate in total employment was recorded in quarter 1 of 2005.

In summary, the descriptive statistics in Table 1 show that across all the East African countries for the study period, the mean quarterly growth rate in total employment lagged behind the mean quarterly growth rate in GDP. Uganda and Tanzania recorded closely the same mean quarterly growth rate in GDP which was higher than the mean quarterly growth rate in GDP for Kenya, while Kenya and Uganda recorded closely the same mean quarterly growth rate in total employment which was higher than the mean quarterly growth rate in total employment for Tanzania.

\subsection{Unit Root Test Results on all Model Variables}

The unit roots are tested on all the variables in the employment equation specified for each country. Table 2 shows the summary of the unit root test results.

For all the East African countries, the ADF- $Z$ statistics as shown in Table 2, indicate that the logarithm of total employment, logarithm of GDP, logarithm of domestic credit and logarithm of FDI variables are non-stationary in level but become stationary in their first difference respectively, suggesting that these variables for all the East African countries are integrated of order one, I (I). The 
Table 2. The unit root test results on all variables in the employment-growth equation.

\begin{tabular}{|c|c|c|c|c|}
\hline Country & Variables & $\begin{array}{c}\text { ADF } Z \text {-stat. in } \\
\text { level }\end{array}$ & $\begin{array}{l}\text { ADF } Z \text {-stat. in } \\
\text { first diff. }\end{array}$ & $\begin{array}{c}\text { Order of } \\
\text { Integration }\end{array}$ \\
\hline \multirow{7}{*}{ Uganda } & Logarithm of total employment & 1.157 & $-2.951^{\star *}$ & $\mathrm{I}(1)$ \\
\hline & Logarithm of GDP & -1.413 & $-3.414^{\star *}$ & $\mathrm{I}(1)$ \\
\hline & Logarithm of domestic credit & -1.692 & $-3.182^{\star *}$ & $\mathrm{I}(1)$ \\
\hline & Logarithm of FDI & -1.902 & $-3.509^{\star * *}$ & $\mathrm{I}(1)$ \\
\hline & Population growth & -1.020 & $-2.898^{\star \star}$ & $\mathrm{I}(1)$ \\
\hline & Inflation & $-3.846^{* * *}$ & - & $\mathrm{I}(0)$ \\
\hline & Lending interest rate & $-2.855^{\star}$ & $-3.489^{\star *}$ & $\mathrm{I}(1)$ \\
\hline \multirow{7}{*}{ Kenya } & Logarithm of total employment & -0.272 & $-3.521^{* *}$ & $\mathrm{I}(1)$ \\
\hline & Logarithm of GDP & -1.358 & $-3.125^{* *}$ & $\mathrm{I}(1)$ \\
\hline & Logarithm of domestic credit & -1.451 & $-3.020^{* *}$ & $\mathrm{I}(1)$ \\
\hline & Logarithm of FDI & -1.921 & $-4.761^{\star * \star}$ & $\mathrm{I}(1)$ \\
\hline & Population growth & -0.579 & $-3.691^{\star * *}$ & $\mathrm{I}(1)$ \\
\hline & Inflation & $-4.036^{\star * *}$ & - & $\mathrm{I}(0)$ \\
\hline & Lending interest rate & $-2.963^{\star *}$ & - & $\mathrm{I}(0)$ \\
\hline \multirow{7}{*}{ Tanzania } & Logarithm of total employment & 0.744 & $-2.891^{\star *}$ & I (1) \\
\hline & Logarithm of GDP & -0.829 & $-3.398^{\star *}$ & $\mathrm{I}(1)$ \\
\hline & Logarithm of domestic credit & $-2.619^{*}$ & $-3.726^{* *}$ & I (1) \\
\hline & Logarithm of FDI & -2.383 & $-4.324^{* * *}$ & $\mathrm{I}(1)$ \\
\hline & Population growth & $-9.123^{\star \star \star}$ & - & $\mathrm{I}(0)$ \\
\hline & Inflation & $-2.694^{*}$ & $-3.879^{* * *}$ & I (1) \\
\hline & Lending interest rate & $-2.855^{*}$ & $-3.489^{* * *}$ & $\mathrm{I}(1)$ \\
\hline
\end{tabular}

Source: Compiled by the authors. ${ }^{\star},{ }^{\star *},{ }^{* *}$ indicate significance at $10 \%, 5 \%$ and $1 \%$ levels respectively.

ADF- $Z$ statistics in Table 2 show that in both Uganda and Kenya, population growth is non-stationary in level but become stationary in its first difference. The ADF- $Z$ statistics in Table 2 however show that for Tanzania, population growth is stationary in level, which suggests that population growth in Tanzania is integrated of order zero, I (0). The ADF- $Z$ statistics in Table 2 indicate that in both Uganda and Kenya, inflation is stationary in levels. However, in Tanzania, inflation becomes stationary in its first difference. These results suggest that in Uganda and Kenya, inflation is integrated of order zero, I (0) but in Tanzania, inflation is intertied of order one, I (1). The ADF- $Z$ statistics in Table 2 further indicate that in both Uganda and Tanzania, lending interest rate is stationary in its first difference. However, in Kenya, lending interest rate becomes stationary in level. These estimates suggest that lending interest rate is I (I) in Uganda and Tanzania but it is I (0) in Kenya.

In summary, the ADF- $Z$ statistics in Table 2 show mixed orders of integration, I (0) and (I) in each of the East African countries. This result prompted this 
study to adopt ARDL bounds testing approach to cointegration as opposed to Belloumi (2014) cointegration methodology. The reason is that the former is suitable for a mix of (0) and (I) variables while the latter is suitable when all variables are I (1).

\subsection{The ARDL Bounds Test Results for Cointegration}

Table 3 shows a summary of the results from the MacKinnon (1996) ARDL bounds testing for cointegration in the employment-growth equations for Uganda, Kenya and Tanzania.

The PSS bounds test results in Table 3 indicate that the null hypothesis is rejected for I (0) variables in the equation for each of the three East African countries because the $\mathrm{p}$-values of $\mathrm{F}$ and $\mathrm{t}$ statistics are not simultaneously greater than Kripfganz \& Schneider (2018) critical values at 5\% significance level. On the other hand, the PSS bounds test results in Table 3 indicate that the null hypothesis is not rejected for I (1) variables in the equation for each of the three East African countries because the $p$-values of $F$ and $t$ statistics are not simultaneously less than Kripfganz \& Schneider (2018) critical values at 5\% significance level. Overall, the PSS bounds test results suggest existence of cointegrating relationships in the equations specified for Uganda, Kenya and Tanzania.

\subsection{The ARDL $\left(p, q_{1}, q_{2}, q_{3}, q_{4}, q_{5}, q_{6}\right)$ Estimates of the Employment-Growth Equations}

Having established evidence of cointegrating relations among variables in the equations specified for each country, we estimate the equation for each country using the ARDL ( $\left.p, q_{1}, q_{2}, q_{3}, q_{4}, q_{5}, q_{6}\right)$ with cointegration. Tables 4(a)-(c) give a summary of the regression estimates for Uganda, Kenya and Tanzania respectively.

The regression estimates in Table 4(a) show that the short run national employment elasticity of economic growth coefficient for Uganda is -0.000671 and is statistically insignificant at 5 percent level of significance. The regression estimates

Table 3. PSS bounds testing for cointegration results.

\begin{tabular}{|c|c|c|c|c|c|}
\hline \multicolumn{6}{|c|}{ Ho: No level relationship/No cointegration } \\
\hline \multirow[t]{2}{*}{ Country } & \multirow{2}{*}{$\begin{array}{l}\text { Estimated } F \\
\text { and } \\
t \text { statistics }\end{array}$} & \multicolumn{2}{|c|}{$\begin{array}{c}\text { Kripfganz \& Schneider (2018) } \\
\text { critical values at } 5 \% \text { significance } \\
\text { level }\end{array}$} & \multicolumn{2}{|c|}{ Approximate $p$-values } \\
\hline & & I (0) variables & I (1) variables & I (0) variables & I (1) variables \\
\hline \multirow{2}{*}{ Uganda } & $F=4.806$ & 3.002 & 4.270 & 0.003 & 0.026 \\
\hline & $t=0.631$ & -2.864 & -4.006 & 0.986 & 0.997 \\
\hline \multirow{2}{*}{ Kenya } & $F=42.786$ & 2.641 & 3.991 & 0.000 & 0.000 \\
\hline & $t=-1.564$ & -2.861 & -4.389 & 0.439 & 0.864 \\
\hline \multirow{2}{*}{ Tanzania } & $F=11.145$ & 2.615 & 3.941 & 0.000 & 0.000 \\
\hline & $t=-0.580$ & -2.854 & -4.405 & 0.832 & 0.978 \\
\hline
\end{tabular}

Source: Compiled by the authors from STATA 14 estimates. 
Table 4. (a) The ARDL $(1,1,4,4,1,0,4)$ with cointegration estimates for Uganda; (b) The ARDL (3, 3, 1, 4, 4, 0, 0) with cointegration estimates for Kenya; (c) The ARDL (2, 1, $2,4,0,4,1)$ with cointegration estimates for Tanzania.

(a)

\begin{tabular}{|c|c|c|c|}
\hline Dependent var: $\Delta$ logarithm of total employment & (1) & (2) & (3) \\
\hline Variables & ADJ & LR & SR \\
\hline \multirow[t]{2}{*}{ First lag of logarithm of total employment } & $0.0518^{* *}$ & & \\
\hline & $(0.0235)$ & & \\
\hline \multirow[t]{2}{*}{ Logarithm of GDP } & & 0.0101 & \\
\hline & & $(0.0617)$ & \\
\hline \multirow[t]{2}{*}{ Population growth } & & $0.413^{* * *}$ & \\
\hline & & $(0.0580)$ & \\
\hline \multirow[t]{2}{*}{ Logarithm of domestic credit } & & 0.100 & \\
\hline & & $(0.0652)$ & \\
\hline \multirow[t]{2}{*}{ Logarithm of FDI } & & $0.0635^{\star *}$ & \\
\hline & & $(0.0251)$ & \\
\hline \multirow[t]{2}{*}{ inflation } & & -0.000274 & \\
\hline & & $(0.00161)$ & \\
\hline \multirow[t]{2}{*}{ Lending Interest rate } & & -0.00410 & \\
\hline & & $(0.00531)$ & \\
\hline \multirow[t]{2}{*}{ D.Logarith of GDP } & & & -0.000671 \\
\hline & & & $(0.00581)$ \\
\hline \multirow[t]{2}{*}{ D.Population growth } & & & -0.0721 \\
\hline & & & $(0.0469)$ \\
\hline \multirow[t]{2}{*}{ LD.Population growth } & & & 0.0100 \\
\hline & & & $(0.0524)$ \\
\hline \multirow[t]{2}{*}{ L2D.Population growth } & & & 0.0185 \\
\hline & & & $(0.0545)$ \\
\hline \multirow[t]{2}{*}{ L3D.Population growth } & & & 0.0369 \\
\hline & & & $(0.0548)$ \\
\hline \multirow[t]{2}{*}{ D.Logarithm of domestic credit } & & & 0.000551 \\
\hline & & & $(0.00751)$ \\
\hline \multirow[t]{2}{*}{ LD.Logarithm of domestic credit } & & & 0.00193 \\
\hline & & & $(0.00722)$ \\
\hline \multirow[t]{2}{*}{ L2D.Logarithm of domestic credit } & & & $-1.46 \mathrm{e}-05$ \\
\hline & & & $(0.00720)$ \\
\hline \multirow[t]{2}{*}{ L3D.Logarithm of domestic credit } & & & -0.00376 \\
\hline & & & $(0.00689)$ \\
\hline D.Logarithm of FDI & & & -0.00295 \\
\hline
\end{tabular}




\section{Continued}

\begin{tabular}{|c|c|c|c|}
\hline & & & $(0.00262)$ \\
\hline D.Lending interest rate & & & $\begin{array}{r}-0.00122^{* * *} \\
(0.000416)\end{array}$ \\
\hline LD.Lending interest rate & & & $\begin{array}{c}0.000292 \\
(0.000442)\end{array}$ \\
\hline L2D.Lending interest rate & & & $\begin{array}{c}0.000366 \\
(0.000455)\end{array}$ \\
\hline L3D.Lending interest rate & & & $0.000742^{\star}$ \\
\hline Cons & & & $\begin{array}{c}-0.577^{\star *} \\
(0.277)\end{array}$ \\
\hline \multicolumn{4}{|l|}{ Sample: $2001 q_{2}-2018 q_{4}$} \\
\hline Observations & 68 & 68 & 68 \\
\hline R-squared & 0.632 & 0.632 & 0.632 \\
\hline
\end{tabular}

Source: Computations from STATA.14. ${ }^{*},{ }^{* *},{ }^{* *}$ indicate significance at $10 \%, 5 \%$ and $1 \%$ levels respectively. Figures in parentheses are standard errors.

(b)

\begin{tabular}{|c|c|c|c|}
\hline Dependent var: $\Delta$ logarithm of total employment & (1) & (2) & (3) \\
\hline Variables & ADJ & LR & SR \\
\hline \multirow[t]{2}{*}{ First lag of logarithm of total employment } & $-0.0846^{\star *}$ & & \\
\hline & $(0.0338)$ & & \\
\hline \multirow[t]{2}{*}{ Logarithm of GDP } & & $0.151^{* *}$ & \\
\hline & & $(0.0639)$ & \\
\hline \multirow[t]{2}{*}{ Population growth } & & $-0.189^{\star *}$ & \\
\hline & & $(0.0882)$ & \\
\hline \multirow[t]{2}{*}{ Logarithm of domestic credit } & & $0.141^{* *}$ & \\
\hline & & $(0.0579)$ & \\
\hline \multirow[t]{2}{*}{ Logarithm of FDI } & & -0.00329 & \\
\hline & & $(0.00665)$ & \\
\hline \multirow[t]{2}{*}{ inflation } & & 0.000863 & \\
\hline & & $(0.000789)$ & \\
\hline \multirow[t]{2}{*}{ Lending interest rate } & & $0.00439^{*}$ & \\
\hline & & $(0.00220)$ & \\
\hline \multirow[t]{2}{*}{ LD. Logarithm of total employment } & & & $0.321^{*}$ \\
\hline & & & $(0.159)$ \\
\hline \multirow[t]{2}{*}{ L2D. Logarithm of total employment } & & & -0.0356 \\
\hline & & & $(0.165)$ \\
\hline \multirow[t]{2}{*}{ D.Logarithm of GDP } & & & 0.0238 \\
\hline & & & $(0.0146)$ \\
\hline
\end{tabular}




\section{Continued}

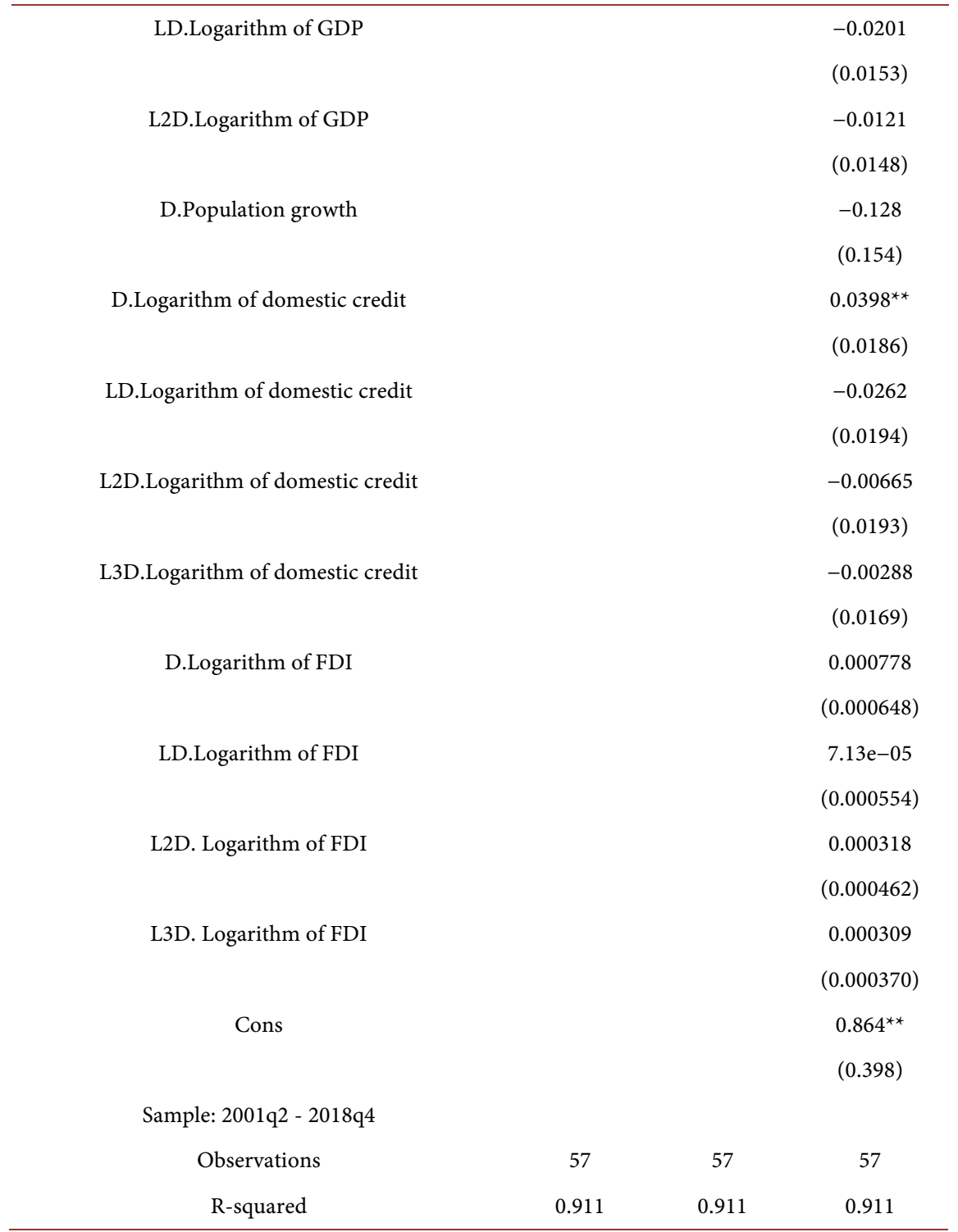

Source: Computations from STATA.14. ${ }^{*},{ }^{*}$ indicate significance at $10 \%$ and $5 \%$ levels respectively. Figures in parentheses are standard errors.

(c)

\begin{tabular}{cccc}
\hline Dependent var: $\Delta$ logarithm of total employment & $(1)$ & $(2)$ & $(3)$ \\
\hline Variables & ADJ & LR & SR \\
\hline First lag of logarithm of total employment & $-0.0328^{\star *}$ & \\
Logarithm of GDP & $(0.0141)$ & & \\
& & -0.415 & \\
Population growth & $(0.368)$ \\
& $1.280^{\star *}$ \\
Logarithm of domestic credit & $(0.544)$ \\
& $0.367^{\star *}$ & \\
\end{tabular}




\section{Continued}

\begin{tabular}{|c|c|c|c|}
\hline Logarithm of FDI & & $\begin{array}{l}-0.0304 \\
(0.0243)\end{array}$ & \\
\hline Inflation & & $\begin{array}{c}0.00427 \\
(0.00582)\end{array}$ & \\
\hline Lending interest rate & & $\begin{array}{l}0.0456^{* *} \\
(0.0179)\end{array}$ & \\
\hline LD.Logarithm of total employment & & & $\begin{array}{c}0.336^{* * *} \\
(0.119)\end{array}$ \\
\hline D.Logarithm of GDP & & & $\begin{array}{l}0.0061^{\star *} \\
(0.00292)\end{array}$ \\
\hline D.Population growth & & & $\begin{array}{c}0.213 \\
(0.141)\end{array}$ \\
\hline LD.Population growth & & & $\begin{array}{c}-0.238^{\star} \\
(0.141)\end{array}$ \\
\hline D.Logarithm of domestic credit & & & $\begin{array}{l}-0.0182 \\
(0.0110)\end{array}$ \\
\hline LD.Logarithm of domestic credit & & & $\begin{array}{l}0.00118 \\
(0.0116)\end{array}$ \\
\hline L2D.Logarithm of domestic credit & & & $\begin{array}{c}-0.00482 \\
(0.0116)\end{array}$ \\
\hline L3D.Logarithm of domestic credit & & & $\begin{array}{l}-0.0144 \\
(0.0107)\end{array}$ \\
\hline D.Inflation & & & $\begin{array}{c}0.000268 \\
(0.000208)\end{array}$ \\
\hline LD.Inflation & & & $\begin{array}{l}-0.000167 \\
(0.000229)\end{array}$ \\
\hline L2D.Inflation & & & $\begin{array}{l}-0.000154 \\
(0.000240)\end{array}$ \\
\hline L3D.Inflation & & & $\begin{array}{l}-0.000199 \\
(0.000250)\end{array}$ \\
\hline D.Lending interest rate & & & $\begin{array}{r}-0.00501^{\star * *} \\
(0.00106)\end{array}$ \\
\hline Cons & & & $\begin{array}{c}0.492^{* * *} \\
(0.124)\end{array}$ \\
\hline Sample: $2001 q_{2}-2018 q_{4}$ & & & \\
\hline Observations & 68 & 68 & 68 \\
\hline R-squared & 0.854 & 0.854 & 0.854 \\
\hline
\end{tabular}

Source: Computations from STATA.14. ${ }^{*}, * *, * *$ indicate significance at $10 \%, 5 \%$ and $1 \%$ levels respectively. Figures in parentheses are standard errors. 
in Table 4(a) also show that the long run national employment elasticity of economic growth coefficient for Uganda is 0.0101 and is statistically insignificant at 5 percent level of significance. These estimates suggest that there is no short run and long run causal connection between Uganda's economic growth and employment growth.

In Table 4(b), estimates show that the short run national employment elasticity of economic growth coefficients for Kenya at first, second and third lagged differences are statistically insignificant at 5 percent level of significance. The regression estimates in Table 4(b) on the other hand indicate that the long run national employment elasticity of economic growth coefficient for Kenya is 0.151 and is statistically significant at 5 percent level of significance. The estimates in Table 4(b) therefore suggest that there is no causal short run connection between Kenya's economic growth and employment growth but there exists a long run causal connection between Kenya's economic growth and employment growth.

The regression estimates in Table 4(c) show that the short run national employment elasticity of economic growth coefficients for Tanzania is 0.0061 and is statistically significant at 5 percent level. On the other hand, the estimates in Table 4 (c) indicate that the long run national employment elasticity of economic growth coefficient for Kenya is -0.415 and is statistically insignificant at 5 percent level of significance. These estimates therefore suggest that there is a short run causal connection between Tanzania's economic growth and employment growth but there is no long run causal connection between Tanzania's economic growth and employment growth.

In summary, the regression estimates in Tables 4(a)-(c) indicate that, for the study period, there is no short run and long run causal connection between economic growth and employment growth in Uganda. For Kenya, estimates show there is no short run causal connection between economic growth and employment growth but there is a long run causal link between the two variables. Lastly for Tanzania, estimates indicate that is a short run causal connection between economic growth and employment growth but there is no long run causal connection between the two variables. Comparing the three countries, the estimates indicate that for Uganda and Tanzania, there is no long run causal link between economic growth and employment growth but there is long run causal link between the two variables in Kenya. On the other hand, estimates indicate that for Uganda and Kenya, there is no short run causal link between economic growth and employment growth but for Tanzania, there is a short run causal link between the two variables.

\section{Discussion of Results}

Among the three traditional East African countries, estimates from this study reveal that there is no long run and short run causal linkage between employment and economic growth in Uganda. These results suggest that economic 
growth in Uganda does not translate to employment creation to Ugandan work force both in the short run and long run. Such results confirm the employment-growth nexus in Uganda and the observed impressive average in the rate of growth in Uganda's GDP could be associated with increased productivity but it could also be attributed to rising unequitable economy expansion in which high growth has been observed in the services sector and from urbanization. The contribution of other economy sectors such as agriculture and industry to Uganda's total GDP has been dismal in the recent past. These results shed some light that Uganda may have been experiencing jobless growth.

Results show that in both Uganda and Tanzania, there is no long run causal connection between economic growth and employment. The estimates show that the long run causal link between the two variables exits in Kenya. Kenya being the largest economy in the East African region as well as the industrial hub of the region, the estimates suggest that unlike Uganda and Tanzania, Kenya's long run economy expansion has potential to absorb a significant number of Kenya's work force into employment. Estimates further indicate that it is only in Tanzania where there is short run causal link between employment and economic growth. Such a result suggests that Tanzania's economy expansion significantly absorbs Tanzania's work force into employment only in the short run. The results further indicate the nonexistence of dynamic equilibrium between Tanzania's goods market and labour market and may also reflect inability of growth in output to sustain absorption of Tanzania's growth in labour force due to demographic factors such as high population growth rates, cumulative unskilled labour and low literacy levels, among other factors.

Estimates indicate that the short run and long run national employment-growth elasticities in the East African region range from -0.415 to 0.151 , quite a lower range reported by many authors in related studies for instance Seyfried (2011) who reported a range of 0.31 to 0.61 for 10 largest states in the United State of America over the study period 1990-2003, Mouelhi \& Ghazali (2014) who reported a rage of $0.48-0.61$ for Tunisia for the period 1980-2012, and many other studies. The range of -0.415 to 0.151 reported in this study implies that, over the study period, all the traditional East African countries did not achieve output growth that is employment intensive. This is because the estimates of the employment elasticities of economic growth are less than unity. These results suggest that the observed impressive average rate of economic growth in the East African countries could have been taking place along with increase in productivity especially labour productivity. Estimates show that in some countries, the employment elasticity of economic growth was positive for instance the long run employment of economic growth elasticity coefficient for Uganda and Kenya, and the short run employment of economic growth elasticity coefficient for Kenya and Tanzania. Uganda registered a negative short run employment elasticity coefficient of economic growth, and Tanzania registered a negative long run employment elasticity coefficient of economic growth. Nega- 
tive employment elasticities of economic growth have been reported by other authors (see for instance, Leshoro (2014), Pini (1997), among others). Yet, some other related studies have reported positive employment elasticities of economic growth (see for instance Seyfried (2011), Ajakaiye et al. (2016), Padalino \& Vivarelli (1997), among others).

\section{Conclusion}

The paper examined the link between employment and economic growth within the East African countries for the study period 2001-2018. Estimates reveal mixed results on the link between economic growth and employment growth across the East African countries. Estimates of the short run and long run employment intensity of economic growth suggest that Uganda's economic growth has no causal connection with employment growth in both the short run and long run. The key study hypothesis is thus not rejected in the case of Uganda. For Kenya, estimates suggest that there is no short run causal connection between Kenya's economic growth and employment growth but there is a long run causal connection between the two variables in the long run. The key study hypothesis is thus partially rejected in the case of Kenya. For Tanzania, estimates suggest that there is a short run causal link between Tanzania's economic growth and employment growth but there is no long run causal connection between the two variables. The key study hypothesis is thus partially rejected in the case of Tanzania. Further, the estimates indicate that the short run and long run national employment-growth elasticities in the East African region range from -0.415 to 0.151 , suggesting that in consideration of the study period, none of the East African countries achieved employment intensity of economic growth. The results thus indicate that economic growth is not the main source of employment creation across the East African countries.

\section{Policy Implications}

The key policy implication derived from the study results is that to enhance employment opportunities for the labour force in the East African countries, it appears prudent for governments to design policies and implement projects and programs that are pro-poor and are growth inclusive. Some of these programs may include: 1) transformation of the agriculture sector where the majority of the work force in East Africa derive livelihood. The transformation effort may entail government intervention to provide access to better inputs, provide adequate and affordable extension services, create and/or support institutions that provide cheap credit to farmers and improve on logistics infrastructure. There should be deliberate strategies to incentivize commercial agriculture by encouraging value chain linkages that create value jobs; 2) reform youth employment programs for instance governments should provide equal opportunity access to skills training and acquisition by both educated and uneducated youth, realigning youth employment programs to prepare graduates for semi-skilled waged 
work in addition to assuring entrepreneurship financing, and develop programs targeting youth involvement in public works; 3 ) The private sector being the major employer, governments should implement policies deliberately to support private sector growth for instance by providing access to cheap capital for investment. Low cost capital enhances growth of the small and medium scale industries which have ability to absorb large numbers of work force into employment. There is need for governments to provide the local investors equal access and opportunities to tax incentives, access to land for industrial sites, including equal opportunities for tax holidays and access to subsidized amenities such as electricity. Private sector growth has potential to increase and sustain wage employment for East African labor force; 4) Governments need to institute a mechanism for international standardization and certification for skills to make East Africa's labor force internationally competitive, and thus encourage labor exporting, and 5) East African governments need to make and implement local content policy to increase employment of local labour and build its capacity at the national levels.

\section{Study Limitations}

This study only concentrated on estimation of the employment intensities of economic growth for the East African countries upon which conclusions about the causal linkage between employment growth and economic growth in the East African countries are derived. The results however do not fully solve the puzzle of impressive growth against disappointing employment growth in the East African region. Further investigation may be undertaken to complement employment elasticities of economic growth in order to assess the possibility of jobless growth in the region.

\section{Conflicts of Interest}

The authors declare no conflicts of interest regarding the publication of this paper.

\section{References}

Ajakaiye, O., Jerome, A. T., Nabena, D., \& Alaba, O. A. (2016). Understanding the Relationship between Growth and Employment in Nigeria. Tokyo: United Nations University.

https://www.brookings.edu/wp-content/uploads/2016/07/growthemployment-nigeriaajakaiye-jerome-nabena-alaba.pdf

Belloumi, M. (2014). The Relationship between Trade, FDI and Economic Growth in Tunisia: An Application of the Autoregressive Distributed Lag Model. Economic Systems, 38, 269-287. https://doi.org/10.1016/j.ecosys.2013.09.002

Boltho, A., \& Glyn, A. (1995). Can Macroeconomic Policies Raise Employment? International Labour Review, 134, 451-470.

Choi, C. K. (2007). The Employment Effects of Economic Growth: Identifying Employment Determinants of Elasticity. Jeonju: Chonbuk National University.

Choi, J., \& Kim, I. (2018). The Relationship between Local Employment Growth and Re- 
gional Economic Growth: Evidence from Korea. In M. Hosoe, I. Kim, M. Yabuta, \& W. Lee (Eds.), Applied Analysis of Growth, Trade, and Public Policy (pp. 35-43). Singapore: Springer. https://doi.org/10.1007/978-981-13-1876-4 3

Dopke (2001). The "Employment Intensity" of Growth in Europe. Kiel Working Paper No. 1021, Kiel: Kiel Institute of World Economics, Germany.

Islam (2004). The Nexus of Economic Growth, Employment and Poverty Reduction: An Empirical Analysis. Discussion Paper, IEPDP 14, Geneva: ILO.

Islam (2010). The Challenge of Jobless Growth in Developing Countries: An Analysis with Cross-Country Data (BIDS Occasional Paper Series No. 1). Dhaka: Dot Printing and Packaging.

Kapsos, S. (2005). The Employment Intensity of Growth: Trends and Macroeconomic Determinants. Employment Strategy Papers 12, Geneva: ILO. https://doi.org/10.1057/97802306273834

Kripfganz, S., \& Schneider, D. C. (2018). ARDL: Estimating Autoregressive Distributed Lag and Equilibrium Correction Models. Proceedings of the 2018 London Stata Conference, London, 6-7 September 2018.

Leshoro, T. L. (2014). Empirical Analysis of Employment Elasticity of Growth in Botswana. Mediterranean Journal of Social Sciences, 5, 171. https://doi.org/10.5901/mjss.2014.v5n2p171

MacKinnon, J. G. (1996). Numerical Distribution Functions for Unit Root and Cointegration Tests. Journal of Applied Econometrics, 11, 601-618. https://doi.org/10.1002/(SICI)1099-1255(199611)11:6<601::AID-JAE417>3.0.CO;2-T

Malmaeus, M. (2010). EC 6901 Kandidatuppsats i nationalekonomi: Potential Consequences of Low or No Economic Growth in Canada and Sweden. http://www.tillvaxtreflektera.se/Rapporter/Malmaeus Econ consequences no growth. pdf

Manh, P., Ngoc, N., \& Ha, D. (2014). Relationship between Economic Growth and Employment in Vietnam. Romanian Economic Journal, 14, 47-67.

Mouelhi, R., \& Ghazali, M. (2014). The Employment Intensity of Output Growth in Unisia and Its Determinants. Economic Research Forum Working Papers No. 857.

Padalino, S., \& Vivarelli, M. (1997). The Employment Intensity of Economic Growth in the G-7 Countries. International Labour Review, 136, 191-213.

Pesaran, M. H., Shin, Y., \& Smith, R. J. (2001). Bounds Testing Approaches to the Analysis of Level Relationships. Journal of Applied Econometrics, 16, 289-326.

https://doi.org/10.1002/jae.616

Pini, P. (1997). Occupazione, Tecnologia e Crescita: Modelli Interpretativi ed Eevidenze Empiriche a Livello Macroeconomico. The Conference of the Accademia Nazionale dei Lincei on "Sviluppo tecnologicoe disoccupazione: Trasformazione della societ", Rome, 16-18 January 1997.

Rangarajan, C. (2006). Employment and Growth (Monograph 2/2006). Chennai: Madras School of Economics.

Revenga, A. L., \& Bentolila, S. (1994). What Affects the Employment Rate Intensity of Growth? The CEPR Conference on Unemployment Policy: How Should Governments Respond to Unemployment, Vigo, 24-27 Septemeber 1994.

Schmid, G. (2008). Full Employment in Europe: Managing Labour Market Transitions and Risks. Northampton, MA: Edward Elgar.

Seyfried, W. (2011). Examining the Relationship between Employment and Economic Growth in the Ten Largest States. Southwestern Economic Review, 32, 13-24. 
Solow, R. M. (1956). A Contribution to the Theory of Economic Growth. Journal of Economics, 70, 65-94. https://doi.org/10.2307/1884513

Thuku, G. K., Omolo, J., \& Muniu, J. (2019). Employment Intensity of Output Growth in Kenya. Journal of Economics and Finance, 10, 9-21.

Turyareeba, D., Ainomugisha, P., Mbabazize, R., Ssebbaale, E. M., Mulema, S., Wemesa, R., Agima, C., \& Bakaki, I. (2020). Employment-Growth Nexus in Uganda. Archives of Business Research, 8, 39-57. https://doi.org/10.14738/abr.87.8463

UN (2014). Africa's Economic Growth Failing to Stimulate Development and Jobs. http://www.theguardian.com/global-development/2014/jan/20/africa-economic-growt hfailing-development-jobs

Walterskirchen, E. (1999). The Relationship between Growth, Employment and Unemployment in the EU. European Economist for an Alternative Economic Policy (TSER Network), Workshop, Barcelona, 16-18 September 1999. 